IZA DP No. 4489

Are Lone Mothers Responsive to Policy Changes? Evidence from a Workfare Reform in a Generous Welfare State

Magne Mogstad

Chiara Pronzato

October 2009 


\title{
Are Lone Mothers Responsive to Policy Changes? Evidence from a Workfare Reform in a Generous Welfare State
}

\author{
Magne Mogstad \\ Statistics Norway, \\ University of Oslo and IZA \\ Chiara Pronzato \\ Bocconi University \\ and Statistics Norway
}

Discussion Paper No. 4489

October 2009

\author{
IZA \\ P.O. Box 7240 \\ 53072 Bonn \\ Germany \\ Phone: +49-228-3894-0 \\ Fax: +49-228-3894-180 \\ E-mail: iza@iza.org
}

Any opinions expressed here are those of the author(s) and not those of IZA. Research published in this series may include views on policy, but the institute itself takes no institutional policy positions.

The Institute for the Study of Labor (IZA) in Bonn is a local and virtual international research center and a place of communication between science, politics and business. IZA is an independent nonprofit organization supported by Deutsche Post Foundation. The center is associated with the University of Bonn and offers a stimulating research environment through its international network, workshops and conferences, data service, project support, research visits and doctoral program. IZA engages in (i) original and internationally competitive research in all fields of labor economics, (ii) development of policy concepts, and (iii) dissemination of research results and concepts to the interested public.

IZA Discussion Papers often represent preliminary work and are circulated to encourage discussion. Citation of such a paper should account for its provisional character. A revised version may be available directly from the author. 


\section{ABSTRACT}

\section{Are Lone Mothers Responsive to Policy Changes? Evidence from a Workfare Reform in a Generous Welfare State*}

There is a heated debate in many European countries about a move towards a welfare system that increases the incentives for lone mothers to move off welfare and into work. We analyze the consequences of a major Norwegian workfare reform of the generous welfare system for lone mothers. Our difference-in-differences estimates show that the policy changes were successful in improving labor market attachment and increasing disposable income of new lone mothers. By contrast, the reform led to a substantial decrease in disposable income and a significant increase in poverty among persistent lone mothers, because a sizeable group was unable to offset the loss of out-of-work welfare benefits with gains in earnings. This suggests that the desired effects of the workfare reform were associated with the side-effects of income loss and increased poverty among a substantial number of lone mothers with insurmountable employment barriers. This finding stands in stark contrast to evidence from similar policy changes in Canada, the UK, and the US, and underscores that policymakers from other developed countries should be cautious when drawing lessons from the successful welfare reforms implemented in Anglo-Saxon countries.

JEL Classification: $\quad \mathrm{C} 23, \mathrm{I32}, \mathrm{I38}, \mathrm{J00}$

Keywords: lone mothers, workfare reform, difference-in-differences, heterogeneity, earnings, labor force participation, poverty, disposable income

Corresponding author:

Magne Mogstad

Research Department

Statistics Norway

P.O. Box 8131 Dep.

$\mathrm{N}-0033$ Oslo

Norway

E-mail:mmo@ssb.no

\footnotetext{
* The Norwegian Research Council has provided financial support for this project. Thanks for helpful comments from Rolf Aaberge, Tony Atkinson, Richard Blundell, Andrea Brandolini, Christian Brinch, Ugo Colombino, John Ermisch, Marco Francesconi, Tarjei Havnes, Terje Skjerpen, Kjetil Telle as well as participants at a number of seminars and conferences.
} 


\section{Introduction}

Most of what we know about how lone mothers respond to policy changes that increase their incentives to move off welfare and into work comes from programme evaluations carried out in Canada, the UK, and the US. The results are striking: the welfare reforms had generally positive average effects on employment, earnings and income as well as reduced programme caseloads and government expenditure. ${ }^{1}$ The Anglo-Saxon experience has fuelled an increasing interest among European policymakers and researchers in policy changes providing stronger work incentives for lone mothers.

Yet caution must be applied when drawing lessons from the Anglo-Saxon experience, as emphasized in several recent review articles (see e.g. Blank, 2002; Moffitt 2007; Brewer et al., 2009). In particular, the reform effects may depend heavily on the broader institutional context and economic environment in which they are implemented. Blank (2002), for instance, points out that countries with widespread public child care, such as in Scandinavia, may find 'making work pay' programs far more effective than countries without such support. On this background, Brewer et al. (2009) conclude that evidence from countries with a different economic and institutional structure than the Anglo-Saxon has significant value for research and policy.

In this paper, we examine the consequences of a major Norwegian workfare reform of the generous welfare system for lone mothers. The aim of these policy changes was to improve the labour market attachment of lone mothers, and in this way increase their ability to be self-sufficient and escape poverty. Interestingly, the reform we study mirrors, in particular, the far-reaching welfare reform implemented in the US in 1996 (replacing the Aid to Families with Dependent Children programme with the Temporary Assistance to Needy Families programme). Both reforms imposed and enforced work requirements and time limits on welfare receipt.

Our study provides first evidence on the effects of the Norwegian workfare reform, making use of a unique household panel data set based on administrative registers covering the entire resident population. Unlike most previous studies of welfare reforms targeting lone mothers, we not only investigate the impacts on the earnings and labor force participation, but also examine the effects on disposable income and poverty. ${ }^{2}$ As theory makes heterogeneous predictions concerning the sign and

\footnotetext{
${ }^{1}$ Lone-parent benefits in the US underwent a major workfare reform in 1996, when time limits and work requirements were imposed, the funding for childcare increased and, in many states, the benefit reduction rates lowered. Moffitt (2007) summarizes the evidence on this much studied reform. In addition, there are a number of programme evaluations of in-work benefit reforms, including Eissa and Liebman (1996) and Meyer and Rosenbaum (2001) of the Earned Income Tax Credit reform in the US, Brewer and Gregg (2001), Blundell et al. (2005) and Francesconi and van der Klaauw (2007) of the Working Families' Tax Credit reform in the UK, as well as Michalopoulos et al. (2005), Card and Hyslop (2006), and Bitler et al. (2008) of the Canadian SelfSufficiency project. Brewer et al. (2009) reviews the evidence from the Working Families' Tax Credit reform. ${ }^{2}$ A notable exception is Blank and Schoeni (2003), who investigates changes in the distribution of family income in the US over the 1990s. Their findings suggest that the welfare reforms led to a rise in family income and a decline in poverty, which align well with Meyer and Sullivan's (2004) study of the consumption pattern of lone mothers during this period.
} 
magnitude of the response of labor supply and disposable income to the reform, we investigate carefully whether the policy changes affected different groups differently. In addition to standard subgroup analysis by the age and educational attainment, we propose an empirical strategy that allows us to pin down the potentially heterogeneous reform effects on new and persistent lone mothers. A priori, both state dependency and heterogeneity can make the responses to policy changes vary systematically with the length of time spent in lone motherhood. ${ }^{3}$ From a policy perspective, the effects on new lone mothers can be of particular interest, because sampling from the flow of new lone mothers avoids oversampling those with long spells of lone motherhood (i.e. length biased sampling), and may therefore provide a more representative picture of the expected impact of the welfare reform on future generations of lone mothers.

To identify the reform effects on new lone mothers, we use a difference-in-differences (DD) method that compares pre-reform and post-reform differences in the average growth rate of the outcome of interest between married mothers who stay married and those who split up and become lone mother (with children of same age). The impact of the reform is then identified as the effect of becoming new lone mother after the reform, relative to before the reform. To account for unobserved permanent differences in the comparison of lone and married mothers in the pre-reform period and the post-reform period, as well as in the comparison of each group across periods, we include individualspecific fixed effects. Our fixed effects specification also addresses the possibility that the transition to lone motherhood is endogenous to the policy reform as long as the fixed effect represents the source of endogeneity. When considering the effects on persistent lone mothers we apply a standard DD approach, comparing the change in the outcome of interest of women who were lone mothers before and after the reform to that of a comparison group of married mothers who remained married (with children of same age). Also in this case, we include individual-specific fixed effects to account for omitted variables bias. To further assess our identification strategies, we perform several specification checks.

We find that the workfare reform was successful in improving the labour market attachment and increasing disposable income of new lone mothers. In contrast, the reform led to a substantial decrease in disposable income and a significant increase in poverty among persistent lone mothers with children of same age, despite an increase in average earnings and employment rate. The reason is that a sizeable group was unable to offset the loss of out-of-work benefits with gains in earnings, even though lone mothers were offered highly subsidized child care, after-school programs were widely available, and the economy was fairly strong. The differences in the estimated reform effects are broadly consistent with predictions from labor supply theory; moreover, the results align well with the fact that persistent lone mothers have considerably weaker labour market attachment, lower education, and higher welfare dependency than new lone mothers.

\footnotetext{
${ }^{3}$ See Heckman (1991) for a discussion about conditions under which state dependency can be separated from heterogeneity. However, the aim of this paper is not to separate the two, but to consider the role of either form of the hand of the past in how lone mothers respond to the workfare reform.
} 
Our finding of income loss and increased poverty among a subgroup of lone mothers with overwhelming employment barriers stands in stark contrast to evidence from similar policy changes in Canada, the UK, and the US (see e.g. Moffitt, 2007; Brewer et al., 2009). Whether these barriers are related to cross-country differences in preferences, institutional factors like labor market regulations and unions, or the designs of the tax-benefit system is an open question. ${ }^{4}$ In any case, our study illustrates that policymakers from other developed countries should be cautious when drawing lessons from the Anglo-Saxon experience.

Our results also speak to a growing literature concerned with heterogeneous impacts of welfare reform. A major concern is that mean impacts for the population of study as a whole may average together positive and negative responses, providing an unsatisfactory evaluation of a policy intervention. The most common way to address heterogeneous responses is to estimate mean impacts for subgroups (defined using education, age, etc), thought to be likely to respond differently to the intervention. However, recent evidence suggests that such subgroup estimations can be incapable in uncovering actual heterogeneous effects of policy interventions (see e.g. Bitler et al., 2006, 2008). Our study demonstrate that considerable heterogeneity can be revealed by taking into account the length of time spent in lone motherhood (that is, in the treatment group), which is a source to heterogeneous reform effects that previous programme evaluations have been silent on. Interestingly, the differential effects between new and persistent lone mothers are not revealed in subgroup analysis by their age and educational attainment.

Section 2 proceeds by describing the Norwegian welfare system for lone mothers, before commenting on predicted effects from labour supply theory of the policy changes. Section 3 outlines our main empirical strategies, whereas Section 4 describes the data. Section 5 assesses the responses of new and persistent lone mothers to the reform, before Section 6 concludes.

\section{Background}

A stylised fact of the Nordic countries is their relatively high employment rates among women in comparison with other OECD-countries. Although this holds true for married (and cohabiting) mothers, it is not the case for lone mothers. ${ }^{5}$ Discrepancies in the relative labour market participation of married and lone mothers across countries may simply reflect compositional differences across the two groups. Yet it seems likely that differences in the design and generosity of welfare schemes tailored to lone mothers also have explanatory power.

\footnotetext{
${ }^{4}$ Whereas Blanchard (2004) emphasises the preference argument for why hours worked is lower in Europe than in the US, Olovsson (2009) argue that differences in taxes can account for the discrepancy and Alesina et al. (2005) stresses the role of labor regulations and unions.

${ }^{5}$ In Norway, the employment rate of lone mothers is significantly lower than that of married mothers. By contrast, in many OECD countries lone mothers are more likely to work than married mothers. Norway also stands out as a country where it traditionally has not paid much to work for lone mothers, due to generous benefits and high effective tax rates. See Bradshaw et al. (1996) for cross-country descriptive statistics of lone mothers' employment and Kjelstad and Rønsen (2004) for an in-depth discussion of the labour market attachment of Norwegian lone mothers.
} 
When it comes to lone-parent benefits, Norway stands out even among the Nordic countries, being the only one with a generous welfare scheme directed exclusively at lone mothers: namely, transitional benefit. There used to be no work requirement for receipt of transitional benefit. Furthermore, transitional benefit carried with it strong work disincentives, since benefit declined rapidly as earnings increased. Note also that the terminology 'transitional benefit' was highly misleading, as lone mothers were free to choose to participate in the scheme for up to ten years. The poor work incentives inherent in transitional benefit may help explain why the employment rate of lone mothers in Norway in the mid-1990s was nearly 10 percentage points lower than that of its neighbours Sweden and Denmark.

Below, we describe in detail the workfare reform of the welfare system for lone mothers, before commenting on predictions from labor supply theory and providing some basic facts on welfare participation rates among lone mothers.

\subsection{Policy changes}

Historically, the transitional benefit scheme has been a generous out-of-work welfare program targeted exclusively at lone mothers. A workfare reform of the transitional benefit scheme was undertaken on 1 January 1998. There were three important changes. First, work requirements were imposed, though only for lone mothers whose youngest child was at least three years old. Second, the upper age limit for the youngest child receiving benefit was reduced and time limits on welfare participation were introduced. Third, in-work benefit levels were raised. Table 1 provides more details on the transitional benefit scheme and the changes made in the 1998 reform.

As the aim of this paper is to evaluate the workfare reform, we will focus attention on lone mothers whose youngest child is older than 3 years, since they were the one faced with work requirements. Another reason for not focusing on lone mothers with younger children is that the Norwegian government introduced in 1998 a cash-for-care reform, which is a cash transfer to married and lone mothers with children aged one or two who did not make or only partly made use of government-subsidized day-care centres. From August to December 1998 the scheme included only one-year-old children, but it was subsequently extended to cover two-year-olds as well. ${ }^{6}$

\footnotetext{
${ }^{6}$ To obtain consistent estimates of the transitional benefit reform on lone mothers with the youngest child less than 3 years of age, it would have been necessary to assume that the cash-for-care reform had the same impact on married and new lone mothers with young children. Schøne (2003) and Naz (2003) find that the reform reduced employment among married mothers, in particular among those with high education.
} 
Table 1. Key features of the transitional benefit reform $(€-1998)$

\begin{tabular}{|c|c|c|}
\hline Characteristic & Before the reform & After the reform \\
\hline Maximum benefit level & $€ 695$ per month & $€ 855$ per month \\
\hline Benefit reduction rate & $\begin{array}{l}40 \text { per cent of earnings exceeding a } \\
\text { threshold of } € 215 \text { per month }\end{array}$ & $\begin{array}{l}40 \text { per cent of earnings exceeding a threshold of } € \\
230 \text { per month }\end{array}$ \\
\hline Work requirements & None & $\begin{array}{l}\text { If youngest child is at least } 3 \text { years old, the lone } \\
\text { parent has to work half time }\end{array}$ \\
\hline Time limit & None & Maximum 3 years of welfare receipt \\
\hline Age limit & $\begin{array}{l}\text { Youngest child less than } 9-10 \\
\text { years old } \\
\left(4^{\text {th }} \text { grade of primary school }\right)\end{array}$ & Youngest child less than 8 years old \\
\hline $\begin{array}{l}\text { Means-testing of benefits } \\
\text { depending on assets }\end{array}$ & None & None \\
\hline
\end{tabular}

\subsection{Work incentives and welfare participation rates}

Figure 1 gives a static perspective of the work incentives stemming from the tax-benefit system before and after the welfare reform in 1998. It shows how disposable income on the vertical axis varies with working hours per week on the horizontal axis; the earnings and welfare components (after tax) are above the 0 line, while the taxes and childcare costs are below. For brevity and with minimal loss of generality, we present only the work incentives for a lone mother with one child who has an hourly wage equal to 75 per cent of the average wage in the labour force. ${ }^{7}$

\footnotetext{
${ }^{7}$ The figure is based on an exact representation of the Norwegian tax-benefit system. Childcare expenses are assumed to increase linearly with working hours. Social assistance and housing benefits, which in Norway are granted at the discretion of social security office staff supplementary to other social policies as last resorts of assistance, are excluded from the incentive structures. Figure 1 may thus overestimate the work incentives. In the figure, the upper limit of the age of the youngest child is set equal to six rather than nine years of age, to reflect the differences in childcare costs for pre-school and school children.
} 
Figure 1. Work incentives before and after the reform for a lone mother with one child 4-6 years of age

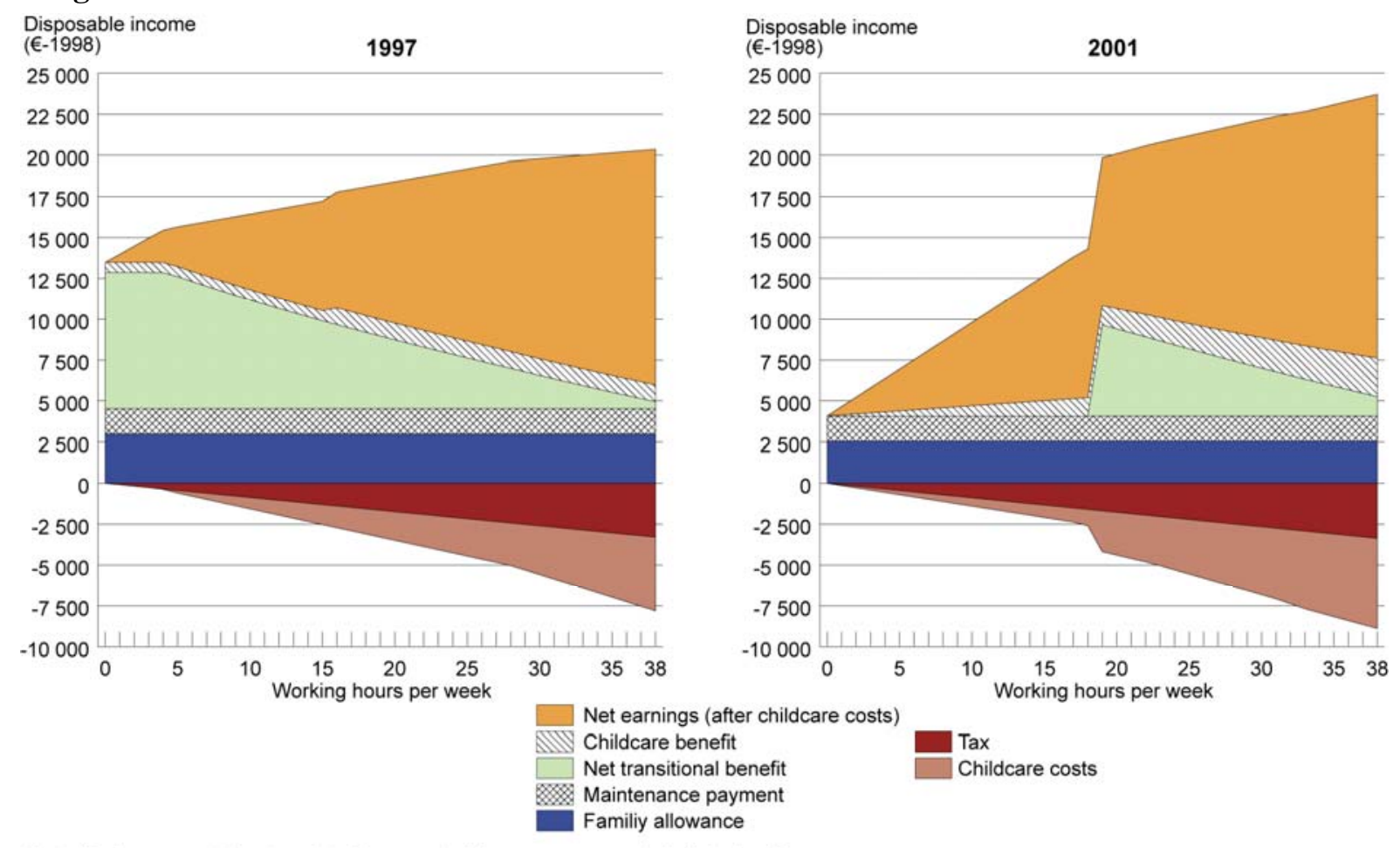

Note: Hourly wage rate is set equal to 75 per cent of the average wage rate in the labour force

Figure 1 illustrates that making lone mothers work at least half time before receiving transitional benefit implies that those working less have incentives to increase labour supply. In contrast, the increase in in-work benefit levels unambiguously discourages labour supply among those working half time or more before the reform (provided that leisure is a normal good). ${ }^{8}$ Altogether, the reform subsidizes part-time work; the average change in labour supply will depend on the size of the different responses, as well as the relative numbers of lone mothers at different points along the budget constraint. The mean impact on the woman's disposable income depends on the extent to which the loss of out-of-work benefits is offset by gains in earnings and higher in-work benefits for part-time workers. In particular, the disposable income will fall and poverty rate rise among lone mothers facing insurmountable employment barriers, who after the reform loose eligibility to transitional benefit.

Figure 1 does not capture the introduction of welfare time limits and the reduction of the upper age limit for the youngest child to the welfare eligibility criteria. The long-term static effect of these measures is to eliminate welfare completely for certain lone mothers, which should increase labour supply for the same reasons that welfare decreases labour supply in the first place. In addition, there are some dynamic effects that unambiguously go in the same direction. First, one may expect lone mothers on welfare to anticipate the date when benefit will run out and begin to intensify their job search or even to accept job offers at an increasing rate when approaching this date. ${ }^{9}$ This implies that the time limits and the upper age limits do not have to be binding to affect the labour supply of welfare

\footnotetext{
${ }^{8}$ Ermisch and Wright (1991) and Meyer and Rosenbaum (2001) suggest that changes in the benefit levels have significant but rather small effects on employment of lone mothers.

${ }^{9}$ Moffitt (1985) and Røed and Zhang (2005) find this behaviour for unemployment insurance recipients approaching the time their benefits will run out.
} 
recipients. An explanation is that if there is uncertainty in terms of job opportunities or randomness in wage offers, one may want to accept an offer that is, in the short run, less attractive than staying on welfare even if it arrives in advance of the date when benefit will run out. Furthermore, the introduction of time limits should provide incentives for recipients who might need welfare in the future to delay the use of welfare benefits, or to leave welfare as rapidly as possible, in order to preserve future eligibility. ${ }^{10}$ The total impact of the change in time and age limits on disposable income and poverty depends on whether earnings increase outweighs loss of transfer payments.

\subsection{Phase-in provisions}

A final important feature of the transitional benefit reform is that phase-in provisions were introduced so that a subgroup of lone mothers who were entitled to and had applied for benefits by 1 January 1998 could continue to receive transitional benefit under the pre-reform rules. The phase-in provisions were gradually phased out and from 1 January 2001 benefits were paid exclusively according to the post-reform rules. Note that women becoming lone mothers after 1 January 1998 were not entitled to the phase-in provisions.

Table 2. Participation rates and average benefit amount for the transitional benefit scheme, 1993-2001

\begin{tabular}{l|cc|}
\hline \multirow{2}{*}{} & \multicolumn{3}{|c|}{$\begin{array}{c}\text { Persistent lone mothers with the youngest } \\
\text { child 3-9 years old }\end{array}$} \\
\hline Year & Welfare participation rate & $\begin{array}{c}\text { Average monthly benefit amount per recipient } \\
(€-1998)\end{array}$ \\
\hline 1993 & 66 & 477 \\
1994 & 65 & 469 \\
1995 & 65 & 460 \\
1996 & 65 & 465 \\
1997 & 65 & 470 \\
1998 & 66 & 524 \\
1999 & 64 & 496 \\
2000 & 61 & 492 \\
2001 & 36 & 449 \\
\hline
\end{tabular}

Notes: In each year, the sample consists of all lone mothers with the youngest child between 4 and 9 years of age.

The welfare participation rates and the benefit amounts presented in Table 2 clearly mirror the fact that reform was gradually phased in. The participation rates for lone mothers declined gradually after the reform in 1998, with a substantial drop in 2001. Further, the average benefit amount for lone mothers with older children declined in 2001; this conforms to intuition, as they were faced with work

\footnotetext{
${ }^{10}$ Grogger (2002), Grogger and Michalopoulos (2003) and Swann (2005) find that the introduction of time limits reduces welfare receipt substantially and that a significant part of this reduction occurs because recipients are forward-looking.
} 
requirements and benefits are reduced when earnings increase. In our estimations, we will pay close attention to the phase-in issue.

\section{Empirical strategy}

This section describes the main empirical strategies that we use to investigate the possibly heterogeneous effects on new and persistent lone mothers of the Norwegian workfare reform described above.

\subsection{Persistent Lone Mothers}

To estimate the impact of the welfare reform on persistent lone mothers, our identification strategy is the following: We start by comparing the change in the outcome of interest from 1997 to 2001 for women who were either lone mother or married mother (with children of same age) in both years. As discussed in more detail below, the reason for using 2001 as the last year of the comparison is that although the reform was undertaken in 1998, it was three years before the policy changes were fully implemented. Since married and lone mothers may react differently to time-specific factors, like business cycle fluctuations, we add a comparison of the change in the outcome from 1993 to 1997 for women who were either lone mother or married mother in both years. This gives us a trend-adjusted DD estimator, exploiting that the reform creates variation along three dimensions: (a) between lone and married mothers; (b) between time periods before and after the reform (1997-2001 versus 19931997); (c) between first (1997 for the 1997-2001 period and 1993 for the 1993-1997 period) and second years (2001 for the 1997-2001 period and 1997 for the 1993-1997 period).

A trend-adjusted DD estimator of the reform effect on persistent lone mothers, $\beta$, can be defined as:

(1) $\beta=\left[\left(\bar{Y}_{01}-\bar{Y}_{97} \mid L O N E=1\right)-\left(\bar{Y}_{01}-\bar{Y}_{97} \mid L O N E=0\right)\right]-\left[\left(\bar{Y}_{97}-\bar{Y}_{93} \mid L O N E=1\right)-\left(\bar{Y}_{97}-\bar{Y}_{93} \mid L O N E=0\right)\right]$

where $\bar{Y}_{t}$ is the average outcome of interest in year $t$, and $L O N E$ is a binary assignment indicator equal to 1 if the woman is a lone mother in both years and 0 if she is a married mother in both years. The first bracket compares the time change in the average outcome for lone and married mothers in the time period after the reform. The second bracket makes the same comparison for the time period before the reform. Whereas the first bracket would be the standard DD estimator of the effect of the reform, the second bracket accounts for the possibility that lone and married mothers have some (unobserved) characteristics that make them react differently to time-specific factors. The identifying assumption is that the relative outcome of lone and married mothers would, on average, have changed in the same way in the period after the reform as in the period before the reform, in the absence of the reform. 
A trend-adjusted DD regression of the reform effect on the persistent lone mothers can be expressed as:

(2) $Y_{i j t}=\alpha_{1}+\alpha_{2}$ REFORM $_{j}+\alpha_{3}$ SECOND $_{t}+a_{4}$ LONE $_{i j}+a_{5}\left(\right.$ REFORM $\left._{j} \times \operatorname{SECOND}_{t}\right)+a_{6}\left(\right.$ REFORM $_{j} \times$ LONE $\left._{i j}\right)$ $+a_{7}\left(\operatorname{SECOND}_{t} \times \operatorname{LONE}_{i j}\right)+\beta\left(R E F O R M_{j} \times \operatorname{SECOND}_{t} \times L O N E_{i j}\right)+\theta X_{i j t}+\varepsilon_{i j t}$,

where $i$ indexes mother, $t$ indexes year $(1=$ second and $0=$ first $), j$ indexes time period $(1$ if the period is $1997-2001,0$ if the period is 1993-1997), $X$ is the local unemployment rate where the mother reside, and $\varepsilon_{i j t}$ is a composite error term consisting of an individual-specific fixed effect and an i.i.d. error term. ${ }^{11}$ The dummy variable $S E C O N D$ is equal to 1 if the year is 2001 for the time period 1997-2001 or 1997 for the time period 1993-1997 (and 0 if the year is 1997 for the time period 1997-2001 or 1993 for the time period 1993-1997). The dummy variable REFORM is equal to 1 if the time period is 1997-2001 (and 0 if the time period is 1993-1997). Equation (2) allows for different intercepts and time-specific effects for lone and married mothers. The reform effect is given by $\beta$, identified from the time change in the average outcome of lone mothers relative to married mothers, in the after reform period relative to the before reform period. In comparison, the conventional DD regression imposes $\alpha_{2}=\alpha_{5}=\alpha_{6}=\beta=0$, and takes $\alpha_{7}$ to be the reform effect.

Previous studies of welfare reforms have generally applied a DD regression to repeated crosssectional data. ${ }^{12}$ As we have access to panel data, we improve on this by restricting the sample to the same lone and married mothers in the first and second year of each time period; this removes biases from comparison over time within each group due to unobserved compositional changes from the first to the second year. Further, we include individual-specific fixed effects to eliminate biases in the comparison between lone and married mothers in a given year owing to permanent unobserved differences between the groups.

\subsection{New Lone Mothers}

To estimate the impact of the policy changes on new lone mothers, who made the transition to lone motherhood after the reform, the following identification strategy is used: We start by comparing the change in the outcome of interest from 1997 to 1999 of mothers who are married in 1997, split up in 1998, and are lone mothers in 1999, with the change in the outcome from 1995 to 1997 of mothers (with children of same age) who are married in 1995, split up in 1996, and are lone mothers in 1997. The reasons for considering the year immediately after the married mother splits up and becomes lone

\footnotetext{
${ }^{11}$ Bertrand et al. (2004) show that the standard errors in DD regressions may be misstated in the presence of serial correlation of outcomes of the same mother over time. Although our fixed effects specification directly account for time-invariant unobserved heterogeneity, the fixed effects do not capture time-varying dependence. However, as their analysis demonstrates, limiting the time dimension to a few years reduces the problem of serial correlation considerably.

${ }^{12}$ A notable exception is Francesconi and van der Klaauw (2007).
} 
mother, and not the year of change itself, are that we have annual data only on the outcomes and that we want to allow the new lone mothers some time to readjust to the new situation. In order to take into account time-specific factors, such as economic fluctuations, that otherwise could confound the estimates of the reform effects, we add a comparison of the change in the outcome of married mothers who stay married from 1997 to 1999 with that of married mothers who stay married from 1995 to 1997.

A DD estimator of the reform effect on new lone mothers, $\delta$, can be defined as:

(3) $\delta=\left[\left(\overline{\mathrm{Y}}_{99}-\overline{\mathrm{Y}}_{97} \mid \mathrm{NEW}=1\right)-\left(\overline{\mathrm{Y}}_{97}-\overline{\mathrm{Y}}_{95} \mid \mathrm{NEW}=1\right)\right]-\left[\left(\overline{\mathrm{Y}}_{99}-\overline{\mathrm{Y}}_{97} \mid \mathrm{NEW}=0\right)-\left(\overline{\mathrm{Y}}_{97}-\overline{\mathrm{Y}}_{95} \mid \mathrm{NEW}=0\right)\right]$

where $N E W$ is a binary assignment indicator equal to 1 if a mother who is married in the first year of the comparison (1997 or 1995) makes the transition to lone motherhood before the last year of the comparison (1999 or 1997), and 0 if she is stays married. The first bracket compares the time change in the average outcome of new lone mothers in the time period after and before the reform. The second bracket makes the same comparison for married mothers staying married. The identifying assumption is that the relative outcome of married mothers making the transition to lone motherhood and those staying married would, on average, have changed in the same way in the period after the reform as in the period before the reform, in the absence of the reform.

A DD regression of the reform effect on new lone mothers can be expressed as:

(4) $Y_{i j t}=\gamma_{1}+\gamma_{2}$ REFORM $_{j}+\gamma_{3}$ SECOND $_{t}+\gamma_{4} N E W_{i j}+\gamma_{5}\left(\right.$ REFORM $\left._{j} \times S E C O N D_{t}\right)+\gamma_{6}\left(\right.$ REFORM $\left._{j} \times N E W_{i j}\right)$ $+\gamma_{7}\left(\operatorname{SECOND}_{t} \times N E W_{i j}\right)+\delta\left(R_{E F O R M_{j}} \times S E C O N D_{t} \times N E W_{i j}\right)+\lambda X_{i j t}+u_{i j t}$,

where $i$ indexes mother, $t$ indexes year $(1=$ second and $0=$ first $)$, and $j$ indexes time period $(1$ if the period is 1997-1999, 0 if the period is 1995-1997), $X$ is the local unemployment rate where the mother reside, and $u_{i j t}$ is a composite error term consisting of an individual-specific fixed effect and an i.i.d. error term. The dummy variable SECOND is equal to 1 if the year is 1999 for the time period 19971999 or 1997 for the time period 1995-1997 (and 0 if the year is 1997 for the time period 1997-1999 or 1995 for the time period 1995-1997). The dummy variable REFORM is equal to 1 if the time period is 1997-1999 (and 0 if the time period is 1995-1997). Equation (4) allows for different intercepts and time-specific effects for married mothers making the transition into lone motherhood and those staying married. The reform effect is given by $\delta$, identified from the time change in the average outcome of the two groups, in the after reform period relative to the before reform period. To examine consistency over time in the reform effects, we also consider other definitions of the post-reform period. For instance, we set REFORM equal to 1 if the time period is 1998-2000, and SECOND equal to 1 if the year is 2000 . 
Taking advantage of our panel data, in each time period we sample only mothers who are married in the first year and either stays married or makes the transition to lone motherhood before the second year. However, there could be unobserved compositional differences between married mothers making the transition into lone motherhood and those staying married, which may affect our estimates of $\delta$ from equation (4). By including individual-specific fixed effects, we account for unobserved permanent differences in the comparison between married mothers staying married and those becoming lone mothers in a given year, and in the comparison of new lone mothers in the time period before and after the reform. Our fixed effect specification also addresses the possibility that the transition to lone motherhood (that is, inclusion in our treatment group) is endogenous to the policy reform as long as the fixed effect represents the source of endogeneity.

\subsection{Phase-in issue}

A complicating issue in many programme evaluations using a DD approach is that welfare reforms are seldom retroactive, so temporary provisions are often introduced during the phase-in period, from when the reform was first enacted to when it has been fully implemented. During this phase-in period, welfare recipients - or a subgroup of welfare recipients - may continue to receive benefits according to pre-reform rules, which blurs the before and after distinction that forms the basis of the DD methods. While several past program evaluations employing the DD approach have simply ignored the potentially confounding effects of a gradual phase-in of reforms, Blundell et al. (2005) decided to exclude observations from a one-year phase-in period in their evaluation of the Working Families' Tax Credit reform in the UK. ${ }^{13}$

In our case, phase-in provisions were introduced so that lone mothers who had applied for and were entitled to benefits before 1998 could continue to receive them under the pre-reform rules for up to three years. As suggested by Table 2, the phase-in period provides limited information about the incentive effects of the reform on persistent lone mothers. To circumvent the phase-in issue, we follow Blundell et al. in excluding the observations from the phase-in years 1998, 1999 and 2000 when estimating the reform effects on persistent lone mothers. To illustrate how the existence of a phase-in period affects the estimated reform effects on persistent lone mothers, we change the definition of the post- and pre-reform period in equation (2). For example, we set REFORM equal to 1 if the time period is 1997-1999 (and 0 if the time period is 1995-1997), and SECOND equal to 1 if the year is 1999 for the time period 1997-1999 or 1997 for the time period 1995-1997 (and 0 if the year is 1997 for the time period 1997-1999 or 1995 for the time period 1995-1997). In comparison, equation (4) has the advantage of avoiding the phase-in issue by sampling from the flow of new lone mothers, who will not be entitled to phase-in provisions if they split up after the reform.

\footnotetext{
${ }^{13}$ The existence of such a phase-in period is not a feature specific to the policy evaluation carried out in this paper; indeed, a gradual phase-in of policy changes appears to be the rule rather than the exception in many OECD countries. For instance, many OECD countries have enacted legislation that gradually will phase out some of the existing openings for early retirement (see Gruber and Wise, 1998).
} 


\section{Data and definitions}

The empirical analysis is based on administrative registers covering the entire resident population of Norway in the period 1993-2001. The register panel data set with household and demographic information is merged with detailed income data from the Tax Assessment Files through unique individual identifiers. The income data are collected from tax records and other administrative registers rather than interviews and self-assessment methods. The coverage and reliability of Norwegian register data are considered to be exceptional, as is documented by the fact that the quality of such national data sets received the highest rating in a data quality survey in the Luxembourg Income Study database (Atkinson et al., 1995). ${ }^{14}$

The population of study comprises all married and lone mothers who in each year were at least 18 years old and not more than 55, whose youngest child was between 4 and 9 years of age. Throughout this paper, we have included mothers who are cohabiting in the 'married' category. Following closely the previous literature, students, self-employed, as well as individuals receiving permanent disability benefits are dropped from the analysis. ${ }^{15}$

For two reasons, this paper do not consider lone father. First, as many as nine lone parents in ten are women. Thus the policy discussion concerning the consequences of the disincentives inherent in the design of lone-parent benefits prior to 1998 primarily relates to lone mothers. Also, the human capital levels and socio-economic status of lone fathers in Norway differ substantially from those of lone mothers, presumably because of the stringent selection criteria for lone fathers to actually get daily custody of their children (Kjeldstad and Rønsen, 2004). Thus pooling lone fathers and lone mothers in an evaluation of the welfare reform is likely to add to the concern for omitted variables bias.

To account for variations in local labour market conditions in the population we make use of data on local unemployment rates for 90 economic regions. Specifically, the economic regions constitute a regional level between country and municipality. The main criteria used for defining the economic regions are labour market, trade and service patterns, as well as commuting and internal migration patterns. Letting economic regions rather than municipalities form the basis for measuring unemployment rates may provide a better predictor of local labour market conditions.

The dependent variables are defined as follows. Our measure of earnings is defined as the woman's annual gross earnings. Disposable income is defined in close agreement with international recommendations (see Expert Group on Household Income Statistics, 2001) and incorporates the woman's annual wages, capital income and all public cash transfers, subtracted taxes. To evaluate the

\footnotetext{
${ }^{14}$ Meyer and Sullivan $(2004,2008)$ advocate the use of consumption data to capture material well-being, due to under-reporting of income in US survey data. However, the Norwegian consumer expenditure survey is a crosssection data set with far too small sample size for our study. Instead, administrative data from tax records appears attractive as the chances of misreporting are minimized. See Røed and Raaum (2003) for a discussion of administrative registers as a valuable, yet largely unexplored, reservoir for microeconometric research.

${ }^{15}$ Eissa and Liebman (1996) and Francesconi and van der Klaauw (2007) use similar sample selection criteria in their reform evaluation of lone-parent benefits.
} 
effects of the reform on annual gross earnings and disposable income, we use the consumer price index to make earnings and incomes from different periods comparable; throughout this paper the reference year is 1998 , and $€ 1$ is set equal to NOK 8.4. The fixed time-specific effects account for general income and earnings growth. The reason for focusing on earnings to evaluate the effects of the reform on labour supply is that we do not have data on hours of work. However, we construct a measure of labour force participation based basic amount thresholds for earnings used by the Norwegian Social Insurance Scheme to determine labour market status (in order to determine eligibility for unemployment benefits, disability benefits, and old-age pension). Specifically, a mother is defined as working if her annual earnings exceed one basic amount (in 1998, about $€ 5,300$ ). Our final outcome is poverty, in which case we follow common practice and define the annual poverty thresholds as 50 per cent of the median in the distribution of annual equivalent disposable income. To enable comparison of household disposable income between individuals belonging to households of varying size and composition, the OECD equivalence scale is applied; the weight of the first adult in the household is set to 1 , each additional adult gets a weight of 0.7 and each child gets a weight equal to 0.5 . In a given year, a woman is defined as poor if her equivalent income is lower than the poverty threshold. The choices of poverty threshold and equivalence scale correspond to what is done in Norwegian official poverty statistics, as well as in the 2002 Poverty White Paper (Ministry of Social Affairs, 2002).

Unfortunately, we are unable to study the long-term impact of the welfare reform as data on lone mothers from after 2001 is not currently available. Note also that our data provides no information on whether or not a woman who was a lone mother before the reform had applied for and thus could receive welfare according to the phase-in rules in the years following the reform; and even if we could tell, it is not clear how we could use this information to evaluate the reform due to the underlying self-selection.

\subsection{Descriptive statistics}

Table 3 displays descriptive statistics of our dependent variables for the persistent lone mothers. As expected, lone mothers have substantially lower earnings and labor force participation than married mothers, but at the same time higher individual disposable income, simply because of the generous welfare system for lone parents. Yet lone mothers are more prone to poverty (based on equivalent household disposable income, in line with common practice and Norwegian official poverty statistics), since lone parent benefit does not appear to fully compensate for being in a single-earner rather than dual-earner family. More importantly, it is evident from Table 3 that there are distinct differences before and after the reform in the changes over time in the outcomes of lone and married mothers. In our trend-adjusted DD framework laid out above, this is suggestive of substantial reform effects on persistent lone mothers. For example, the difference in earnings between married mothers and persistent lone mothers is considerably smaller in the second year than in the first year, in the period 
after the reform relative to the period before the reform; specifically, equation (1) suggests that the workfare reform increased the earnings of persistent lone mothers by $€ 1,128$. In comparison, a standard DD approach without trend adjustments, as defined by the first bracket in equation (1), would suggest a reform effect on earnings of $€ 1,009$.

Table 3. Pre-reform and post-reform descriptive statistics of married mothers and persistent lone mothers

\begin{tabular}{|c|c|c|c|c|c|}
\hline & \multirow{3}{*}{$\begin{array}{l}\text { - Level - } \\
\text { Lone mothers } \\
\text { Pre-reform } \\
\text { First year } \\
\text { (1993) }\end{array}$} & \multicolumn{4}{|c|}{$\begin{array}{l}\text {-Difference }- \\
\text { Lone mothers - Married mothers }\end{array}$} \\
\hline & & \multicolumn{2}{|c|}{ Pre-reform } & \multicolumn{2}{|c|}{ Post-reform } \\
\hline & & $\begin{array}{l}\text { First year } \\
(1993)\end{array}$ & $\begin{array}{c}\text { Second year } \\
(1997)\end{array}$ & $\begin{array}{l}\text { First year } \\
\text { (1997) }\end{array}$ & $\begin{array}{c}\text { Second year } \\
(2001)\end{array}$ \\
\hline \multicolumn{6}{|l|}{ Outcomes (mean) } \\
\hline Earnings $(€-1998)$ & 9958 & -4101 & -4220 & -4523 & -3514 \\
\hline Labor force part. (percent) & 52.6 & -22.8 & -17.2 & -20.2 & -10.3 \\
\hline Disposable income $(€-1998)$ & 17676 & 5123 & 5447 & 6222 & 5720 \\
\hline Poverty (percent) & 4.7 & 2.0 & 2.8 & 3.3 & 7.6 \\
\hline \multicolumn{6}{|l|}{ Characteristics (mean) } \\
\hline Age & 29.9 & -3.4 & -3.4 & -2.9 & -2.9 \\
\hline Years of schooling & 11.1 & -1.0 & -1.0 & -1.1 & -1.1 \\
\hline Labour market experience & 18.1 & -8.5 & -8.5 & -10.9 & -10.9 \\
\hline Non-western immigrant \% & 2.6 & 0.4 & 0.4 & 1.0 & 1.0 \\
\hline Number of children & 1.6 & -0.7 & -0.7 & -0.6 & -0.6 \\
\hline Age of the youngest child & 3.0 & 0.2 & 0.3 & 0.4 & 0.4 \\
\hline Unemployment rate $\%$ & 4.3 & 0.1 & 0.1 & 0.1 & 0.1 \\
\hline Observations & 10,992 & 90,171 & 90,171 & 93,116 & 93,116 \\
\hline Pop. share of lone mothers & & .122 & .122 & .113 & .113 \\
\hline \multicolumn{6}{|c|}{$\begin{array}{l}\text { Notes: Pre-reform sample consists of women who were either lone mother or married mother in both } 1993 \text { (first year) and } \\
1997 \text { (second year). Post-reform sample consists of women who were either lone mother or married mother in both } 1997 \\
\text { (first year) and } 2001 \text { (second year). Level refers to means for lone mothers in first year of the pre-reform period. Difference } \\
\text { refers to differences in means between lone and married mothers in first/second year in pre-reform/post-reform period. } \\
\text { Labour market experience points are measured in the first year, and defined according to the standard of the National } \\
\text { Insurance Administration, as years of pension points (depending on years in employment) interacted with average number of } \\
\text { pension points (depending on level of previous earnings). }\end{array}$} \\
\hline
\end{tabular}

Table 3 also shows descriptive characteristics of married and lone mothers before and after the reform. As is clear from Table 3, married mothers are, on average, older and have more children, higher education, and more labor market experience than persistent lone mothers. However, we are not too concerned with differences in the characteristics of these two groups per se. Given the DD specification with fixed effects in equation (2), our primary concern is that there could be differences in how time-varying characteristics of lone and married mothers change over time, in the period after the reform relative to the period before the reform. Among the variables listed in Table 3, only the local unemployment rates give such a cause for concern. We see, however, that there is almost no difference in the change over time in the local unemployment rate where lone and married mothers reside, in the pre-reform period relative to the post-reform period.

Table 4 shows the same descriptive statistics as Table 3, except for new lone mothers instead of persistent lone mothers. Again, there are signs of substantial reform effects. For example, equation 
(3) suggests that the workfare reform increased disposable income of the new lone mothers by as much as $€ 2,447$. It is also evident that married mothers are, on average, older and have slightly more children and somewhat higher labor market experience and education than the new lone mothers. However, there is almost no difference in the change over time in the local unemployment rate where lone and married mothers reside, in the pre-reform period relative to the post-reform period. When comparing Tables 3 and 4, it is clear that the persistent lone mothers are younger and have considerably weaker labor market attachment and lower education, relative to the new lone mothers. This manifests itself in new lone mothers having fairly similar labor force participation and earnings as married mothers (cf. Column 2 displaying second year averages before the reform, but after the woman has become lone mother).

Table 4. Pre-reform and post-reform descriptive statistics of married mothers and new lone mothers

\begin{tabular}{|c|c|c|c|c|c|}
\hline & \multirow{3}{*}{$\begin{array}{l}\text { - Level - } \\
\text { Lone mothers } \\
\text { Pre-reform } \\
\text { First year } \\
(1995)\end{array}$} & \multicolumn{4}{|c|}{$\begin{array}{c}- \text { Difference }- \\
\text { Lone mothers }- \text { Married mothers }\end{array}$} \\
\hline & & \multicolumn{2}{|c|}{ Pre-reform } & \multicolumn{2}{|c|}{ Post-reform } \\
\hline & & $\begin{array}{c}\text { First year } \\
(1995)\end{array}$ & $\begin{array}{c}\text { Second year } \\
(1997)\end{array}$ & $\begin{array}{l}\text { First year } \\
(1997)\end{array}$ & $\begin{array}{c}\text { Second year } \\
(1999)\end{array}$ \\
\hline \multicolumn{6}{|l|}{ Outcomes (means) } \\
\hline Earnings $(€-1998)$ & 16962 & 972 & 368 & 486 & 289 \\
\hline Labor force part. (percent) & 82.1 & 1.9 & -2.4 & 1.8 & -0.3 \\
\hline Disposable income $(€-1998)$ & 15762 & 1528 & 8530 & 225 & 9674 \\
\hline Poverty (percent) & 2.3 & -0.1 & 2.3 & 0.7 & 2.2 \\
\hline \multicolumn{6}{|l|}{ Characteristics (mean) } \\
\hline Age & 33.0 & -2.3 & -2.3 & -2.2 & -2.2 \\
\hline Years of schooling & 11.8 & -0.3 & -0.3 & -0.4 & -0.4 \\
\hline Labour market experience & 27.2 & -3.5 & -3.3 & -5.2 & -5.1 \\
\hline Non-western immigrant \% & 2.4 & 0.0 & 0.0 & 0.1 & 0.1 \\
\hline Number of children & 2.1 & -0.3 & -0.3 & -0.2 & -0.2 \\
\hline Age of the youngest child & 6.6 & -0.2 & -0.2 & -0.2 & -0.2 \\
\hline Unemployment rate \% & 3.6 & 0.0 & 0.0 & 0.1 & 0.0 \\
\hline Observations & 2,276 & 83,186 & 83,186 & 87,402 & 87,402 \\
\hline Pop. share of lone mothers & - & .027 & .027 & .027 & .027 \\
\hline
\end{tabular}

Notes: Pre-reform sample of lone mothers consists of women who were married in 1995 (first year), split up in 1996, and are lone mothers in 1997 (second year). Pre-reform sample of married mothers consists of mothers who stay married from 1995 (first year) to 1997 (second year). Post-reform sample of lone mothers consists of women who were married in 1997 (first year), split up in 1998, and are lone mothers in 1999 (second year). Post-reform sample of married mothers consists of mothers who stay married from 1997 (first year) to 1999 (second year). Level refers to means for lone mothers in first year of the pre-reform period. Difference refers to differences in means between lone and married mothers in first/second year in prereform/post-reform period. Labour market experience points are measured in the first year, and defined according to the standard of the National Insurance Administration, as years of pension points (depending on years in employment) interacted with average number of pension points (depending on level of previous earnings). 


\section{The responses of lone mothers to the welfare reform}

This section investigates the responses of new and persistent lone mothers to the workfare reform, before reporting estimates of the reform effects during the phase-in-period and results from several robustness checks.

\subsection{Estimates of reform effects}

Table 5 shows the estimated mean impact of the workfare reform on earnings, labour force participation, disposable income and poverty of persistent and new lone mothers. As discussed above, the reform is expected to stimulate the labour market attachment of lone mothers as long as the positive effects from the time and the age limits as well as the work requirements dominate the negative effect induced by the increase in in-work benefit levels of those working at least part-time. Indeed, Table 5 shows positive and significant reform effects on earnings and labour force participation (after adjusting for inflation and controlling for overall economic growth among women through the time-specific fixed effects). Specifically, the reform led to a 2.2 percentage points increase in the labour force participation of new lone mothers and a $€ 406$ increase in their earnings. In comparison, the reform is estimated to have increased the earnings of persistent lone mothers by $€$ 1,116 , and to have raised labour force participation with 4.3 percentage points. The differences in the labour market responses of new and persistent lone mother are consistent with the predictions from labour supply theory. Since the reform essentially subsidizes part-time work, the average response will depend on the relative number of lone mothers at different points along the budget constraint (as well as the elasticity of the two groups). As the persistent lone mothers had relatively weak labour market attachment before the reform they will, on average, have stronger incentives to increase their labour supply in response to the policy changes, compared to new lone mothers.

Table 5. Estimates of reform effects on new and persistent lone mothers

\begin{tabular}{|c|c|c|c|c|c|c|}
\hline \multirow[b]{2}{*}{ Dependent variable: } & \multicolumn{3}{|c|}{ Panel A: Persistent lone mothers } & \multicolumn{3}{|c|}{ Panel B: New lone mothers } \\
\hline & Estimate & Mean & Obs. & Estimate & Mean & Obs. \\
\hline Earnings $(€-1998)$ & $\begin{array}{c}1116^{* * *} \\
(121)\end{array}$ & 13,872 & 366,574 & $\begin{array}{c}406^{* *} \\
(186)\end{array}$ & 18,557 & 341,176 \\
\hline Labor force part. (perc. points) & $\begin{array}{c}4.3^{* * *} \\
(0.7)\end{array}$ & 67.0 & 366,574 & $\begin{array}{c}2.2^{* *} \\
(1.0)\end{array}$ & 82.1 & 341,176 \\
\hline Disposable income $(€-1998)$ & $\begin{array}{c}-844 * * * \\
(139)\end{array}$ & 21,974 & 366,574 & $\begin{array}{c}2447 * * * \\
(231)\end{array}$ & 25,053 & 341,176 \\
\hline Poverty (perc. points) & $\begin{array}{c}3.5 * * * \\
(0.4)\end{array}$ & 4.7 & 366,574 & $\begin{array}{l}-0.9 \\
(0.7) \\
\end{array}$ & 4.3 & 341,176 \\
\hline
\end{tabular}

*** significant at $1 \%$ level, ** significant at $5 \%$ level, $*$ significant at $10 \%$ level.

Notes: Each column in each panel is a separate estimation. All estimations include individual-specific and time-specific fixed effects, as well as controls for local unemployment rate where the mother resides. Outcomes are defined in Section 4 . For the binary dependent variables, the standard errors in parentheses are robust to heteroskedasticity. Mean refers to average outcome of lone-mothers in the second year in the pre-reform period (1997). In Panel A, estimations are based on OLS on equation (2), with 1993-1997 as the pre-reform period and 1997-2001 as the post-reform period. In Panel B, estimations are based on OLS on equation (4), with 1995-1997 as the pre-reform period and 1997-1999 as the post-reform period. 
Turning attention to disposable income and poverty, the last two columns of Table 5 confirms the picture of stark differences in the responses of new and lone mothers to the workfare reform. On the one hand, the policy changes led to a substantial increase in the disposable income of new lone mothers, in part because of higher earnings but also due to higher in-work benefit levels. On the other hand, the workfare reform caused a decrease in disposable income and a significant increase in poverty among persistent lone mothers. The reason is that a sizeable group was unable to offset the loss of out-of-work benefits with gains in earnings, even though lone mothers were offered highly subsidized child care, after-school programs were widely available, and the economy was fairly strong. This suggests that the desired effects of the workfare reform were associated with the income loss and increased poverty among a subgroup of lone mothers with overwhelming employment barriers. The difference in the estimated reform effects on poverty and disposable income align well with the fact that the persistent lone mothers have considerably weaker labour market attachment, lower education, and higher welfare dependency than new lone mothers.

As shown in Table 5, estimating the average responses of the population of lone mothers as a whole may conceal important differences in the consequences of the reform between new and persistent lone mothers. This may also hold true within the groups of new and persistent lone mothers. Table 6 investigates this, running equation (2) and (4) separately by the age and educational level of the lone mothers. As expected, the reform effects are less precisely estimated and must be interpreted with caution. With this caveat in mind, the sub-sample results generally conform to the estimated mean impacts reported in Table 5. This suggests that the essential features of our empirical findings of differences in the responses of new and persistent lone mothers could not have been revealed using mean impact analysis on typically defined subgroups of lone mothers. Table 5 also shows that there are signs of stronger positive reform effects on earnings and labour force participation among persistent and new lone mothers with low education, whose labour market attachment is particularly weak before the reform. In contrast, for high educated lone mothers who were already working a lot prior to the reform, the point estimates for earnings and labour force participation are considerably smaller, and in one case even negative. As discussed above, these results align well with predictions from labour supply theory. 
Table 6. Sub-sample estimates of reform effects on new and persistent lone mothers

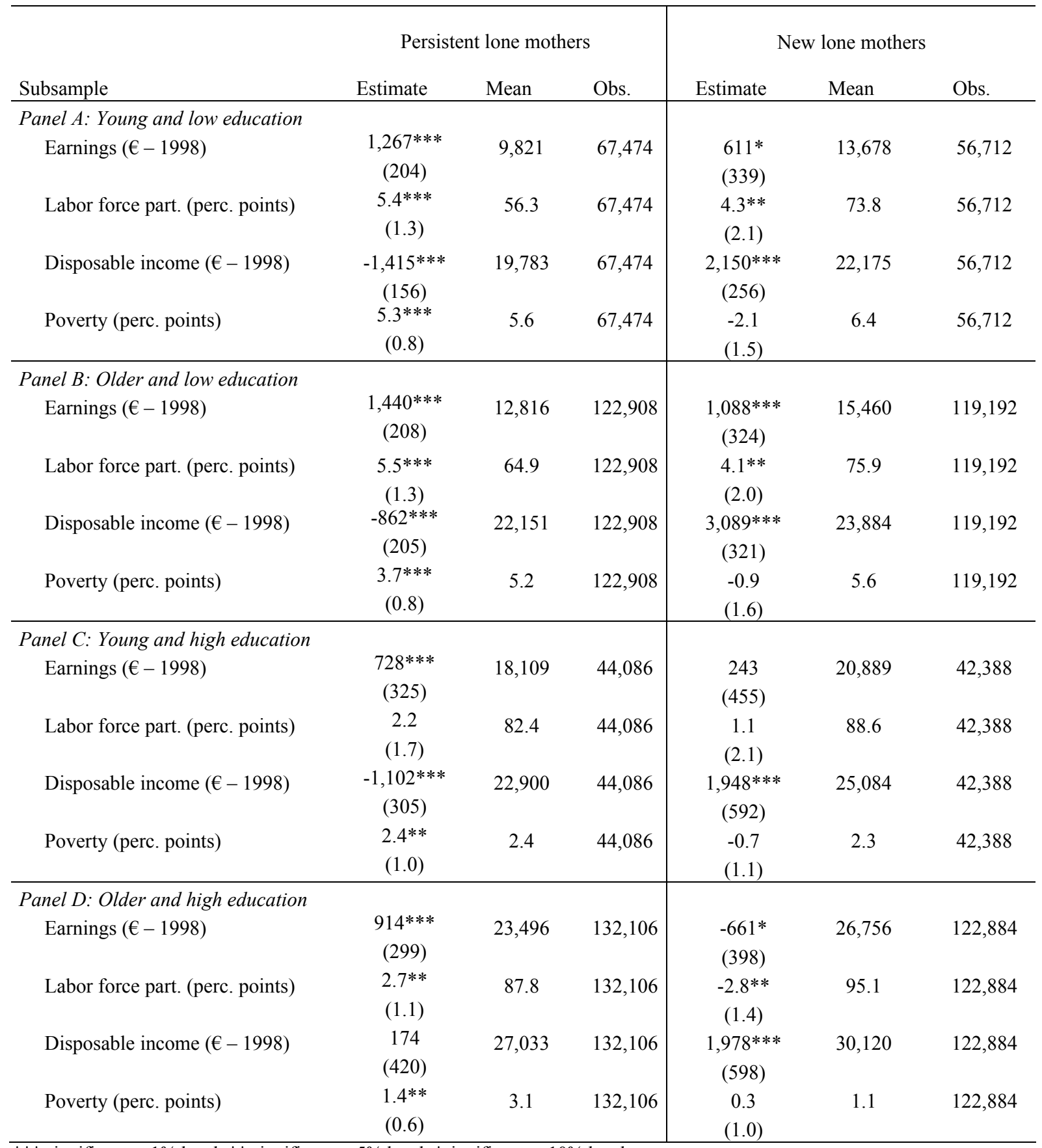

*** significant at $1 \%$ level, $* *$ significant at $5 \%$ level, *significant at $10 \%$ level.

Notes: Each column in each panel for new and persistent lone mothers is a separate estimation. High educated is defined as attended college, whereas Older is defined as at least 35 years of age in the second year. All estimations include individualspecific and time-specific fixed effects, as well as controls for local unemployment rate where the mother resides. Outcomes are defined in Section 4. For the binary dependent variables, the standard errors in parentheses are robust to heteroskedasticity. Mean refers to average outcome of lone-mothers in the second year in the pre-reform period (1997). Persistent lone mothers: All estimations are based on OLS on equation (2), with 1993-1997 as the pre-reform period and 1997-2001 as the post-reform period. New lone mothers: All estimations are based on OLS on equation (4), with 1995-1997 as the pre-reform period and 1997-1999 as the post-reform period.

\subsection{Phase-in issue}

As discussed in detail above, the workfare reform was gradually phased in, so that lone mothers who had applied for and were entitled to benefits before 1998 could continue to receive them under prereform rules for up to three years. While several past programme evaluations have typically ignored 
the potentially confounding effects of a gradual phase-in of reforms, we have in sub-section 5.1 followed Blundell et al. (2005) and discounted the observations from the phase-in years when estimating the reform effects on persistent lone mothers. In comparison, the empirical strategy for new lone mothers sidesteps these issues, as they were not entitled to phase-in provisions if they split up after the reform.

Table 7. Estimates of reform effects on new and persistent lone mothers in the phase-in period

\begin{tabular}{|c|c|c|c|c|c|c|}
\hline \multirow[b]{2}{*}{ Last year in post-reform period } & \multicolumn{3}{|c|}{ Persistent lone mothers } & \multicolumn{3}{|c|}{ New lone mothers } \\
\hline & Estimate & Mean & Obs. & Estimate & Mean & Obs. \\
\hline \multicolumn{7}{|l|}{ Panel A: 1998} \\
\hline Earnings $(€-1998)$ & $\begin{array}{c}193 * * * \\
(52)\end{array}$ & 15,810 & 425,732 & $\begin{array}{l}445^{* *} \\
(185)\end{array}$ & 18,557 & 338,360 \\
\hline Labor force part. (perc. points) & $\begin{array}{l}0.6^{*} \\
(0.3)\end{array}$ & 73.5 & 425,732 & $\begin{array}{c}1.6 \\
(1.0)\end{array}$ & 82.1 & 338,360 \\
\hline Disposable income $(€-1998)$ & $\begin{array}{c}260 \\
(570)\end{array}$ & 23,183 & 425,732 & $\begin{array}{c}2,029 * * * \\
(314)\end{array}$ & 25,053 & 338,360 \\
\hline Poverty (perc. points) & $\begin{array}{l}-0.2 \\
(0.2) \\
\end{array}$ & 4.5 & 425,732 & $\begin{array}{l}-1.1 \\
(0.7) \\
\end{array}$ & 4.3 & 338,360 \\
\hline \multicolumn{7}{|l|}{ Panel B: 1999} \\
\hline Earnings $(€-1998)$ & $\begin{array}{c}337 * * * \\
(78)\end{array}$ & 15,116 & 396,746 & $\begin{array}{c}406^{* *} \\
(186)\end{array}$ & 18,557 & 341,176 \\
\hline Labor force part. (perc. points) & $\begin{array}{c}1.3 * * * \\
(0.5)\end{array}$ & 71.1 & 396,746 & $\begin{array}{l}2.2 * * \\
(1.0)\end{array}$ & 82.1 & 341,176 \\
\hline Disposable income $(€-1998)$ & $\begin{array}{c}112 \\
(119)\end{array}$ & 22,633 & 396,746 & $\begin{array}{c}2,447 * * * \\
(231)\end{array}$ & 25,053 & 341,176 \\
\hline Poverty (perc. points) & $\begin{array}{l}-0.3 \\
(0.3)\end{array}$ & 4.3 & 396,746 & $\begin{array}{l}-0.9 \\
(0.7)\end{array}$ & 4.3 & 341,176 \\
\hline \multicolumn{7}{|l|}{ Panel C: 2000} \\
\hline Earnings $(€-1998)$ & $\begin{array}{c}413 * * * \\
(100)\end{array}$ & 14,510 & 379,836 & $\begin{array}{c}428 * * \\
(186)\end{array}$ & 18,557 & 340,856 \\
\hline Labor force part. (perc. points) & $\begin{array}{c}2.4 * * * \\
(0.6)\end{array}$ & 68.9 & 379,836 & $\begin{array}{l}1.5^{*} \\
(0.9)\end{array}$ & 82.1 & 340,856 \\
\hline Disposable income $(€-1998)$ & $\begin{array}{l}-247 \\
(167)\end{array}$ & 22,396 & 379,836 & $\begin{array}{c}2,193 * * * \\
(313)\end{array}$ & 25,053 & 340,856 \\
\hline Poverty (perc. points) & $\begin{array}{c}0.1 \\
(0.3) \\
\end{array}$ & 4.4 & 379,836 & $\begin{array}{l}-0.1 \\
(0.7) \\
\end{array}$ & 4.3 & 340,856 \\
\hline
\end{tabular}

\footnotetext{
*** significant at $1 \%$ level, ** significant at 5\% level, * significant at $10 \%$ level.
}

Notes: Each column in each panel for new and persistent lone mothers is a separate estimation. All estimations include individualspecific and time-specific fixed effects, as well as controls for local unemployment rate where the mother resides. Outcomes are defined in Section 4. For the binary dependent variables, the standard errors in parentheses are robust to heteroskedasticity. Mean refers to average outcome of lone-mothers in the second year in the pre-reform period (1997). Persistent lone mothers: All estimations are based on OLS on equation (2). In Panel (A), 1996-1997 is the pre-reform period and 1997-1998 is the post-reform period. In Panel (B), 1995-1997 is the pre-reform period and 1997-1999 is the post-reform period. In Panel (C), $1994-1997$ is the pre-reform period and 1997-2000 is the post-reform period. New lone mothers: All estimations are based on OLS on equation (4), with 1995-1997 as the pre-reform period. In Panel (A), 1996-1998 is the post-reform period. In Panel (B), 1997-1999 is the postreform period. In Panel (C), 1998-2000 is the post-reform period.

Table 7 report estimates of reform effects on persistent lone mothers in 1998, 1999 and 2000, clearly suggesting that we would seriously underestimate the impact of the policy changes if we were to disregard or were unaware of the gradual phase-in of the reform. As expected, the reform effects on earnings and labour force participation increase as the end of the phase-in period ( $1^{\text {st }}$ of January 2001) 
approaches. From a policy point of view, it is also interesting to see that there are no detrimental reform effects on poverty and disposable income among persistent lone mothers during the phase-in period, when they could self-select into the new system with higher in-work benefits or stay on the old-system without work requirements. Table 7 also displays reform effects on new lone mothers in the phase-in years, showing strong consistency over time in the estimates. This finding illustrates that it is unnecessary to wait until the phase-in period is over to evaluate the reform effects on new lone mothers, which can be attractive from a policy perspective. Also, the consistency over time in the estimates increases our confidence in this empirical strategy.

\subsection{Specification checks}

This section performs three different specification checks to assess our identification strategies. First, we relax the linearity restriction on our controls, before conducting placebo reforms and investigating whether the reform affected the transition into lone motherhood. It should be also be noted that for or simplicity of interpretation, we have throughout this paper employed a linear probability model (adjusting for heteroskedasticity in the standard errors) in cases where the dependent variable is binary. ${ }^{16}$ However, Chamberlain fixed-effects logit models produce similar marginal effects estimates. For brevity, the results are omitted but available upon request.

As noted by Meyer (1995) and discussed further in for example Adebie (2005), introducing controls in a linear fashion may not be appropriate if the reform has different effects for different groups of the population. In particular, differences in the characteristics of lone mothers relative to married mothers before and after the reform may cause non-parallel dynamics in the outcome variable of the two groups. To account for compositional changes, we use a standard survey weighting procedure (see e.g. Yansaneh, 2005), with sampling weights equal to the inverse probability of sampling married/lone mothers with certain characteristics (reported in Tables 3 and 4) in the period before/after the reform. Specifically, the system of weights is constructed as follows: For the populations of lone and married mothers before and after the reform, we partition each sample into 64 subgroups according to their age, education, work experience, and immigrant status, as well as the number of children and the age of the youngest child. After performing this weighting procedure (separately) for the population of women used in Table 5 to study the effects on persistent lone mothers (Panel A) and new lone mothers (Panel B), we re-estimate equations (2) and (4) on the weighted samples. Tables A.1 and A.2 presented in the Appendix confirm that lone and married mothers have very similar characteristics in the weighted sample. Table 8 shows estimation results based on the weighted samples: the reform effects are qualitatively the same and the point estimates

\footnotetext{
${ }^{16}$ In the cases of the binary outcomes, our linear probability model will be the best least-squares approximation to the true conditional expectation function. As noted by Angrist (2001), if there are no covariates or they are discrete, linear models are no less appropriate for binary dependent variables than for other types of dependent variables.
} 
are rather similar to those reported in Table 5, suggesting that the linearity restriction in the controls is little cause for concern in our application.

Table 8. Estimates of reform effects on new and persistent lone mothers. Weighted sample

\begin{tabular}{lccc|ccc}
\hline & \multicolumn{3}{c|}{ Panel A: Persistent lone mothers } & \multicolumn{3}{c}{ Panel B: New lone mothers } \\
& Estimate & Mean & Obs. & Estimate & Mean & Obs. \\
Dependent variable: & $1,039^{* * *}$ & 13,872 & 366,316 & $351^{*}$ & 18,586 & 339,988 \\
\hline Earnings $(€-1998)$ & $(164)$ & & & $(209)$ & & \\
& $3.5^{* * *}$ & 67.0 & 366,316 & $1.7 *$ & 82.2 & 339,988 \\
Labor force part. (perc. points) & $(0.9)$ & & & $(1.0)$ & & 339,988 \\
& $-1,142^{* * *}$ & 21,974 & 366,316 & $2,273^{* * *}$ & 25,062 & \\
Disposable income $(€-1998)$ & $(131)$ & & & $(206)$ & & 339,988 \\
& $3.1 * * *$ & 4.6 & 366,316 & -1.0 & 4.2 & $(0.7)$ \\
\hline
\end{tabular}

*** significant at $1 \%$ level, ** significant at $5 \%$ level, *significant at $10 \%$ level.

Notes: Each column in each panel is a separate estimation based on the weighted sample. All estimations include individualspecific and time-specific fixed effects. Outcomes are defined in Section 4. For the binary dependent variables, the standard errors in parentheses are robust to heteroskedasticity. Mean refers to average outcome of lone-mothers in the second year in the pre-reform period (1997). In Panel A, estimations are based on OLS on equation (2), with 1993-1997 as the pre-reform period and 1997-2001 as the post-reform period. In Panel B, estimations are based on OLS on equation (4), with 1995-1997 as the pre-reform period and $1998-2000$ as the post-reform period

As a further specification check, we conduct placebo reforms where we pretend that the workfare reform took place before the actual implementation, and then estimate the effects of these placeboreforms using data from the pre-reform period. If we find an effect of the actual timing of the reform, but no effect for the placebo-reforms, we will be more confident in our empirical strategies. Further, the sign of the effect of the placebo reform may give an indication of which direction our welfare reform estimates could be biased. To perform the placebo-reforms, we change the definition of the dummy variables SECOND and REFORM in equations (2) and (4), so that only observations from the pre-reform period are used. Table 9 displays estimates of placebo reform effects on persistent and new lone mothers. For both groups, these estimates are insignificant and generally rather small; And if anything, the sizeable positive point estimate for disposable income of persistent lone mothers indicates that the actual reform impact reported in Table 6 understates the reduction in disposable income.

Another concern is that the transition to lone motherhood (that is, inclusion in our treatment group) could be endogenous to the policy reform. The workfare reform may influence the incentives to become lone mother in two conflicting ways. On the one hand, the work requirements and time and age limits may have made it more costly to be lone mother, thereby providing weaker incentives for entering lone motherhood. On the other hand, the increase in in-work benefit levels may improve the outside option of marriage, strengthening the incentives for entering lone motherhood. Our fixed effect specification controls for this insofar the fixed effect represents the source of endogeneity.

To investigate this further, Figure 2 displays the time trend in the probability of becoming lone mother, for married mothers with the youngest child aged 10-14 and married mothers with the 
youngest child aged 4-9. Only the latter group was affected by the reform. As is evident from the figure, there is a good coherence between the time trends before the reform, and more importantly, it's heartening to find no change in the relative probability of lone motherhood at the time or after the reform. This conforms well to a vast amount of evidence from program evaluations carried out in the US, which show insignificant effects of welfare reforms on family composition (Moffitt, 2007).

Table 9. Estimates of placebo-reform effects on new and persistent lone mothers

\begin{tabular}{lccc|ccc}
\hline & \multicolumn{3}{c|}{ Panel A: Persistent lone mothers } & \multicolumn{3}{c}{ Panel B: New lone mothers } \\
& Estimate & Mean & Obs. & Estimate & Mean & Obs. \\
Dependent variable: & 116 & 13,746 & 369,506 & -107 & 16,603 & 325,180 \\
\hline Earnings $(€-1998)$ & $(90)$ & & & $(171)$ & & \\
& 0.9 & 66.6 & 369,506 & 0.2 & 79.2 & 325,180 \\
Labor force part. (perc. points) & $(0.6)$ & & & $(1.0)$ & & 325,180 \\
& 703 & 20,808 & 369,506 & 346 & 22,677 & \\
Disposable income $(€-1998)$ & $(733)$ & & & $(279)$ & & 325,180 \\
& 0.4 & 4.3 & 369,506 & 1.2 & 4.0 & $(0.7)$ \\
\hline
\end{tabular}

*** significant at $1 \%$ level, ** significant at $5 \%$ level, * significant at $10 \%$ level.

Notes: Each column in each panel is a separate estimation. All estimations include individual-specific and time-specific fixed effects, as well as controls for local unemployment rate where the mother resides. Outcomes are defined in Section 4. For the binary dependent variables, the standard errors in parentheses are robust to heteroskedasticity. Mean refers to average outcome of lone-mothers in the second year in the pre-reform period (1997). In Panel A, estimations are based on OLS on equation (2), with 1993-1996 as the pre-reform period and 1994-1997 as the post-reform period. In Panel B, estimations are based on OLS on equation (4), with 1993-1995 as the pre-reform period and 1995-1997 as the post-reform period.

Figure 1. Time trends in the probability of becoming lone mother for married mothers with the youngest child between 4 and 9 years or between 10 and 14 years

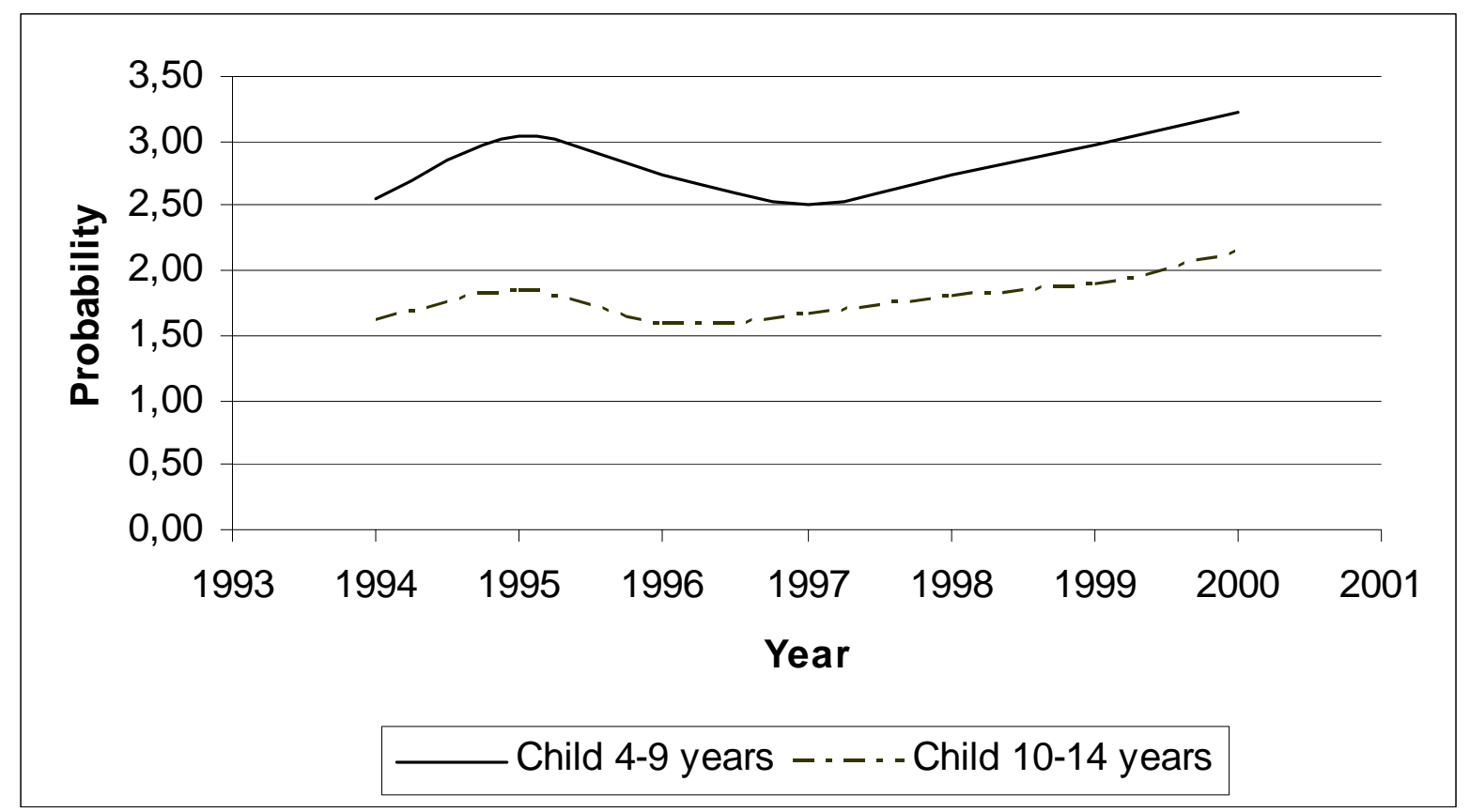

Notes: In each year, the sample consists of married mothers with the youngest child between 4 and 9 years of age or between 10 and 14 years of age. The probability of becoming lone mother is calculated as the fraction of married mothers in a given year who are lone mother in the subsequent year. 


\section{Conclusion}

The generous Nordic model of welfare is commonly viewed as an exceptional success, in terms of equality, economic growth, and female labour force participation. ${ }^{17}$ However, it recently became evident that subgroups of the population with weak labour market attachment and high welfare dependency, such as lone mothers, were overrepresented among the poor. This prompted a major workfare reform of the Norwegian welfare system for lone mothers: work requirements were brought in, time limits imposed, age limits reduced and in-work benefit levels raised. In this paper, we provide first evidence on the impacts of these policy changes.

Our analysis shows that the policy changes were successful in improving the labour market attachment and increasing disposable income of new lone mothers. In contrast, the reform led to a substantial decrease in disposable income and significant increase in poverty among persistent lone mothers with children of same age. The reason is that a sizeable group was unable to offset the loss of out-of-work welfare benefits with gains in earnings, even though lone mothers were offered highly subsidized child care mothers, after-school programs were widely available, and the economy was fairly strong. This suggests that the desired effects of the workfare reform were associated with the side-effects of income loss and increased poverty among a subgroup of lone mothers with insurmountable employment barriers.

As most of what we know about the responses to such policy changes comes from Canada, the UK, and the US, evidence drawn from the institutional context of a generous welfare state should be of particular interest. Our finding of a decline in disposable income and a rise in poverty among stand in stark contrast to the evidence from a similar workfare reform implemented in the US in 1996: In a survey of the research on this reform, Moffitt (2007; p31) concludes "That the 1996 welfare reform was a success, in overall terms and on average, is almost universally accepted by policy analysts and researchers". The disparity in the responses of lone mothers to workfare reforms across two of EspingAndersen's (1990) highly differentiated worlds of welfare capitalism underscores that policymakers in other developed countries should be cautious when drawing lessons from the Anglo-Saxon experience.

Our finding of large differences in the responses of new and persistent lone mothers also speaks to a growing literature concerned with heterogeneous impacts of welfare reforms. Recent evidence from this literature suggests that mean impact analysis on typically defined subgroups can be incapable in uncovering actual heterogeneous effects of policy intervention (see e.g. Bitler et al., 2006, 2008). Our study demonstrate, however, that considerable heterogeneity in the responses to the policy changes can actually be revealed by taking into account the length of time spent in lone motherhood that is, the treatment group), which is a source to heterogeneous reform effects that previous programme evaluations have been silent on.

\footnotetext{
${ }^{17}$ For example, the EU summit at Hampton Court in October 2005 on globalization and social models had an agenda that centered on the "Nordic model". The International Herald Tribune in an article in September 2005 says, "European leaders want to know how Sweden and its Nordic neighbors, so heavily laden with cradle-tograve welfare systems, float high above the struggling economies of much of the rest of the Continent."
} 


\section{References}

Abedie, A. (2005): "Semiparametric Difference-in-Differences Estimators", Review of Economic Studies, 72, 1-19.

Alesina, A., E. Glaeser, and B. Sacerdote (2005): "Work and Leisure in the US and Europe: Why so Different?", in M. Gertler and K. Rogoff (eds.) NBER Macroeconomics Annual, Cambridge, MA: MIT Press.

Angrist, J. (2001): "Estimations of Limited Dependent Variable Models with Dummy Endogenous Regressors: Simple Strategies for Empirical Practice,” Journal of Business \& Economic Statistics, 19, $2-16$.

Atkinson, A., L. Rainwater and T. Smeeding (1995): Income Distribution in OECD Countries, Paris, OECD.

Bertrand, M., E. Duflo and S. Mullainathan (2004): "How Much Should We Trust Differences-inDifferences Estimates?", Quarterly Journal of Economics, 119, 249-75.

Blanchard, O. (2004): “The Economic Future of Europe”, NBER Working Paper, 10310.

Blank, R. (2002): “US Welfare Reform: What's Relevant for Europe?”, CESifo Working Paper, 753.

Blank, R. and R. Schoeni (2003): “Changes in the Distribution of Children's Family Income over the 1990's", American Economic Review Papers and Proceedings, 304-308.

Bitler, M., J. Gelbach, and H. Hoynes (2006): "What Mean Impacts Miss: Distributional Effects of Welfare Reform Experiments', American Economic Review, 96, 988-1012.

Bitler, M., J. Gelbach, and H. Hoyes (2008): "Distributional Impacts of the Self-Sufficiency Project", Journal of Public Economics, 2, 748-765.

Blundell, R., M. Brewer and A. Shephard (2005): "Evaluating the Labour Market Impact of Working Families' Tax Credit Using Difference-in-Differences", Working Paper, Institute for Fiscal Studies.

Bradshaw, J., S. Kennedy, M. Kilkey, S. Hutton, A. Corden, T. Eardley, H. Holmes and J. Neale (1996): Policy and the Employment of Lone Parents: A Comparison of Policy in 20 Countries, London, SPRC.

Brewer, M., and P. Gregg (2001): "Lone Parents, the WFTC and Employment in Households with Children", in R. Dickens, J. Wadsworth and P. Gregg (eds), The State of Working Britain, London, LSE Centre for Economic Performance.

Brewer, M., M. Francesconi, P. Gregg, and J. Grogger (2009): "Feature: In-Work Benefit Reform in a Cross-National Perspective - Introduction”, Economic Journal, 119, 1-14.

Card, D. and D. Hyslop (2006): "The Dynamic Effects of an Earnings Subsidy for Long-Term Welfare Recipients: Evidence from the SSP Applicant Experiment”, NBER Working Paper, 12774.

Eissa, N., and J. Liebman (1996): "Labor Supply Response to the Earned Income Tax Credit", Quarterly Journal of Economics, 111, 605-37.

Ermisch, J., and R. Wright (1991): "Welfare Benefits and Lone Parents' Employment in Great Britain", Journal of Human Resources, 24, 424-56. 
Esping-Andersen, G. (1990): The Three Worlds of Welfare Capitalism, Princeton, Princeton University Press.

Expert Group on Household Income Statistics (2001): Final Report and Recommendations, Ottawa.

Francesconi, M., and W. van der Klaauw (2007): "The Socioeconomic Consequences of "In-Work" Benefit Reform for British Lone mothers", Journal of Human Resources, 17, 1-31

Grogger, J. (2002): "The Behavioral Effects of Welfare Time Limits", American Economic Review, 98, 385-9.

Grogger, J., and C. Michalopoulos (2003): "Welfare Dynamics under Time Limits", Journal of Political Economy, 111, 530-54.

Gruber, J., and D. Wise (1998): Social Security Programs and Retirement around the World, Chicago, University of Chicago Press.

Heckman, J. (1991): "Identifying the hand of the past: distinguishing state dependence from heterogeneity", American Economic Review, 81, 71-79.

Kjelstad, R., and M. Rønsen (2004): "Welfare Rules, Business Cycles, and Employment Dynamics among Lone Parents in Norway", Feminist Economics, 10, 61-89.

Meyer, B. (1995): "Natural and Quasi-Experiments in Economics", Journal of Business and Economic Statistics, 13, 151-161.

Meyer, B., and D. Rosenbaum (2001): "Welfare, the Earned Income Tax Credit, and the Labor Supply of Single Mothers", Quarterly Journal of Economics, 117, 1063-114.

Meyer, B. and D. Sullivan (2004): "The Effects of Welfare and Tax Reforms: The Material WellBeing of Single Mothers in the 1980s and the 1990s", Journal of Public Economics, 88, 1387-1420.

Meyer, B. and D. Sullivan (2008): "Changes in the Consumption, Income, and Well-Being of Single Mother Headed Families", forthcoming American Economic Review.

Michalopoulos, C., P. K. Robins and D. Card (2005): "When financial work incentives pay for themselves: evidence from a randomised social experiment for welfare recipients", Journal of Public Economics, 89, 5-29.

Ministry of Social Affairs (2002): "Plan of Action for Combating Poverty", Poverty White Paper, Norwegian Ministry of Social Affairs.

Moffitt, R. (1985): "Unemployment Insurance and the Distribution of Unemployment Spells", Journal of Econometrics, 28, 85-101.

Moffitt, R. (2007): "Welfare Reform: The US Experience", forthcoming in Swedish Economic Review. Naz, G. (2004): "The Impact of Cash-Benefit Reform on Parents' Labour Force Participation", Journal of Population Economics, 17, 369-83.

Olovsson, C. (2009): “Why Europeans Work so Little?”, International Economic Review, 50, 39-61.

Røed, K., and O. Raaum (2003): "Administrative Registers - Unexplored Reservoirs of Scientific Knowledge?", Economic Journal, 113, 258-81. 
Røed, K., and T. Zhang (2005): "Unemployment Duration and Economic Incentives: A QuasiRandom Assignment Approach”, European Economic Review, 49, 1799-825.

Schøne, P. (2003): "Labor Supply Response to a Cash-for-Care Reform", Journal of Population Economics, 17, 703-27.

Swann, C. (2005): "Welfare Reform When Recipients Are Forward-Looking", Journal of Human Resources, 40, 31-56.

Yansaneh, I. S. (2005): "Construction and Use of Sample Weights", in United Nation Statistics Division (ed.), Designing Household Surveys Samples: Practical Guidelines, New York, United Nations. 


\section{Appendix}

Table A1. Pre-reform and post-reform descriptive statistics of married mothers and persistent lone mothers. Weighted sample

\begin{tabular}{|c|c|c|c|c|c|}
\hline & \multirow{3}{*}{$\begin{array}{l}\text { - Level- } \\
\text { Lone mothers } \\
\text { Pre-reform } \\
\text { First year } \\
\quad(1993)\end{array}$} & \multicolumn{4}{|c|}{$\begin{array}{c}\text {-Difference }- \\
\text { Lone mothers }- \text { Married mothers }\end{array}$} \\
\hline & & \multicolumn{2}{|c|}{ Pre-reform } & \multicolumn{2}{|c|}{ Post-reform } \\
\hline & & $\begin{array}{c}\text { First year } \\
(1993)\end{array}$ & $\begin{array}{l}\text { Second year } \\
(1997)\end{array}$ & $\begin{array}{l}\text { First year } \\
(1997)\end{array}$ & $\begin{array}{c}\text { Second year } \\
(2001)\end{array}$ \\
\hline \multicolumn{6}{|l|}{ Outcomes (mean) } \\
\hline Earnings $(€-1998)$ & 9958 & -2209 & -2444 & -1990 & -1173 \\
\hline Labor force part. (percent) & 52.6 & -15.8 & -13.6 & -12.3 & -6.5 \\
\hline Disposable income $(€-1998)$ & 17676 & 6950 & 7256 & 8762 & 7944 \\
\hline Poverty (percent) & 4.7 & -0.4 & 2.3 & 1.7 & 7.5 \\
\hline \multicolumn{6}{|l|}{ Characteristics (mean) } \\
\hline Age & 33.9 & -0.3 & -0.3 & -0.4 & -0.4 \\
\hline Years of schooling & 11.1 & -0.1 & -0.1 & 0.0 & 0.0 \\
\hline Labour market experience & 18.1 & -1.6 & -1.6 & -1.9 & -1.9 \\
\hline Non-western immigrant \% & 2.6 & 0.0 & 0.0 & 0.0 & 0.0 \\
\hline Number of children & 1.6 & -0.1 & -0.1 & -0.1 & -0.1 \\
\hline Age of the youngest child & 3.0 & 0.1 & 0.1 & 0.2 & 0.2 \\
\hline Unemployment rate $\%$ & 4.3 & 0.1 & 0.1 & 0.1 & 0.0 \\
\hline
\end{tabular}

Notes: See Table 3. The weighting procedure is explained in Section 5.

Table A2. Pre-reform and post-reform descriptive statistics of married mothers and new lone mothers. Weighted sample

\begin{tabular}{lccccc} 
& $\begin{array}{c}\text { Level }- \\
\text { First year } \\
\text { Pre-reform }\end{array}$ & \multicolumn{2}{c}{ Lone mothers - Married mothers } \\
& $\begin{array}{c}\text { Pre-reform } \\
\text { Lone mothers } \\
(1995)\end{array}$ & $\begin{array}{c}\text { First year } \\
(1995)\end{array}$ & $\begin{array}{c}\text { Second } \\
\text { year } \\
(1997)\end{array}$ & $\begin{array}{c}\text { First year } \\
(1997)\end{array}$ & $\begin{array}{c}\text { Second } \\
\text { year } \\
(1999)\end{array}$ \\
& & & & & \\
& 16974 & 1596 & 1002 & 1668 & 1425 \\
\hline Outcomes (means) & 82.2 & 2.9 & -1.6 & 4.0 & 1.1 \\
Earnings $(€-1998)$ & 15765 & 2060 & 9046 & 1259 & 10518 \\
Labor force part. (percent) & 2.3 & -0.2 & 2.4 & 0.6 & 2.2 \\
Disposable income $(€-1998)$ & & & & & \\
Poverty (percent) & 35.0 & -0.6 & -0.6 & -0.5 & -0.5 \\
Characteristics (mean) & 11.8 & -0.1 & -0.1 & -0.1 & -0.1 \\
Age & 27.2 & -0.2 & -0.2 & -0.4 & -0.4 \\
Years of schooling & 2.1 & 0.0 & 0.0 & 0.0 & 0.0 \\
Labour market experience & 2.1 & -0.1 & -0.1 & -0.1 & -0.1 \\
Non-western immigrant $\%$ & 6.6 & 0.0 & 0.0 & 0.0 & 0.0 \\
Number of children & 3.6 & 0.0 & 0.0 & 0.0 & 0.0 \\
Age of the youngest child & & & &
\end{tabular}

Notes: See Table 4. The weighting procedure is explained in Section 5. 